Article

\title{
Three-Dimensional Cadmium(II) \\ Cyanide Coordination Polymers with Ethoxy-, Butoxy- and Hexyloxy-ethanol
}

\author{
Takeshi Kawasaki ${ }^{1}$ and Takafumi Kitazawa ${ }^{1,2, *}$ \\ 1 Department Chemistry, Faculty of Science, Toho University, 2-2-1, Miyama, Funabashi, \\ Chiba 274-8510, Japan; takeshi.kawasaki@sci.toho-u.ac.jp \\ 2 Research Centre for Materials with Integrated Properties, Toho University, 2-2-1 Miyama, Funabashi, \\ Chiba 274-8510, Japan \\ * Correspondence: kitazawa@chem.sci.toho-u.ac.jp; Tel.: +81-47-472-5077; Fax: +81-47-475-5077 \\ Academic Editor: Helmut Cölfen \\ Received: 28 July 2016; Accepted: 17 August 2016; Published: 24 August 2016
}

\begin{abstract}
The three novel cadmium(II) cyanide coordination polymers with alkoxyethanols, $\left[\mathrm{Cd}(\mathrm{CN})_{2}\left(\mathrm{C}_{2} \mathrm{H}_{5} \mathrm{OCH}_{2} \mathrm{CH}_{2} \mathrm{OH}\right)\right]_{\mathrm{n}}(\mathrm{I})$, $\left[\left\{\mathrm{Cd}(\mathrm{CN})_{2}\left(\mathrm{C}_{4} \mathrm{H}_{9} \mathrm{OCH}_{2} \mathrm{CH}_{2} \mathrm{OH}\right)\right\}_{3}\left\{\mathrm{Cd}(\mathrm{CN})_{2}\right\}\right]_{n}$ (II) and $\left[\left\{\mathrm{Cd}(\mathrm{CN})_{2}\left(\mathrm{H}_{2} \mathrm{O}\right)_{2}\right\}\left\{\mathrm{Cd}(\mathrm{CN})_{2}\right\}_{3} \cdot 2\left(\mathrm{C}_{6} \mathrm{H}_{13} \mathrm{OCH}_{2} \mathrm{CH}_{2} \mathrm{OH}\right)\right]_{n}$ (III), were synthesized and charcterized by structural determination. Three complexes have three-dimensional $\mathrm{Cd}(\mathrm{CN})_{2}$ frameworks; I has distorted tridymite-like structure, and, II and III have zeolite-like structures. The cavities of $\mathrm{Cd}(\mathrm{CN})_{2}$ frameworks of the complexes are occupied by the alkoxyethanol molecules. In I and II, hydroxyl oxygen atoms of alkoxyethanol molecules coordinate to the Cd(II) ions, and the Cd(II) ions exhibit slightly distort trigonal-bipyramidal coordination geometry. In II, there is also tetrahedral Cd(II) ion which is coordinated by only the four cyanides. The hydroxyl oxygen atoms of alkoxyethanol connects etheric oxygen atoms of the neighboring alkoxyethanol by hydrogen bond in I and II. In III, hexyloxyethanol molecules do not coordinate to the $\mathrm{Cd}$ (II) ions, and two water molecules coordnate to the octahedral $\mathrm{Cd}$ (II) ions. The framework in III contains octahedral Cd(II) and tetrahedral Cd(II) in a 1:3 ratio. The $\mathrm{Cd}(\mathrm{CN})_{2}$ framework structures depended on the difference of alkyl chain for alkoxyethanol molecules.
\end{abstract}

Keywords: coordination polymer; crystal structure; self-assembly; mineralomimetic chemistry; host-guest; molecular size; hydrogen bond

\section{Introduction}

Cadmium(II) cyanide of formula $\mathrm{Cd}(\mathrm{CN})_{2}$ and the related compounds have interesting, unique chemical properties [1-11]. Cadmium(II) cyanide is a three-dimensional porous coordination polymer, and is the clathration of various guest molecules (ex. $\mathrm{CCl}_{4}$ [1,2], $\mathrm{CH}_{2} \mathrm{ClCHCl}_{2}$ [3] and $\mathrm{Bu}_{2} \mathrm{O}$ [3]) by van der Waals force in the cavity. It is interesting that the structures of host constructed from $\mathrm{Cd}(\mathrm{II})$ and cyanide ions change according to the guest [1-10], and the hosts form a mineralomimetic framework. The coordination geometry of $\mathrm{Cd}(\mathrm{II})$ in $\mathrm{Cd}(\mathrm{CN})_{2}$ is normally tetrahedral four-coordination geometry (denoted as $\mathrm{Cd}_{\mathrm{T}}$ ) but the geometry might also be trigonal-bipyramidal five-coordination geometry $\left(\mathrm{Cd}_{\mathrm{TB}}\right)$ or octahedral six-coordination geometry $\left(\mathrm{Cd}_{\mathrm{OC}}\right)$ according to the influence of other ligand (ex. $\mathrm{H}_{2} \mathrm{O}$ [6-10]). At $\mathrm{Cd}(\mathrm{CN})_{2}$ clathrates containing lipophilic guest, coordination geometries of $\mathrm{Cd}(\mathrm{II})$ were $\mathrm{Cd}_{\mathrm{T}}$, the $\mathrm{Cd}(\mathrm{CN})_{2}$ frameworks were cristobalite-like or tridymite-like structures [1-4,11]. On the other hand, the $\mathrm{Cd}(\mathrm{CN})_{2}$ clathrates with water molecule(s) coordinating to $\mathrm{Cd}$ (II) ion contained alcohol or short dialkyl-ether (alkyl group of carbon number less than 3) as a guest, and the host frameworks performed zeolite-mimetic structures [6-10]. Thus, it was 
thought that the guest hydrophilic groups influence the $\mathrm{Cd}(\mathrm{II})$ coordination environment. We are interested in the effect of the coexistence of two kinds of hydrophilic groups on the $\mathrm{Cd}(\mathrm{II})$ coordination environment. Alkoxyethanol has both hydroxyl and etheric groups as shown Scheme 1. We report herein the synthesis and crystal structures of three novel cadmium(II) cyanide complexes with alkoxyethanol compounds of formulae $\left[\mathrm{Cd}(\mathrm{CN})_{2}(\text { Etcel })\right]_{\mathrm{n}}(\mathrm{I}),\left[\left\{\mathrm{Cd}(\mathrm{CN})_{2}(\text { Bucel })\right\}_{3}\left\{\mathrm{Cd}(\mathrm{CN})_{2}\right\}\right]_{\mathrm{n}}(\mathrm{II})$ and $\left[\left\{\mathrm{Cd}(\mathrm{CN})_{2}\left(\mathrm{H}_{2} \mathrm{O}\right)_{2}\right\}\left\{\mathrm{Cd}(\mathrm{CN})_{2}\right\}_{3} \cdot 2(\text { Hexcel })\right]_{n}$ (III) (Etcel = ethoxyethanol, Bucel = butoxyethanol, Hexcel $=$ hexyloxyethanol).

$$
\mathrm{R}^{-} \overbrace{\mathrm{OH}}\left(\mathrm{R}=\mathrm{C}_{2} \mathrm{H}_{5}, \mathrm{C}_{4} \mathrm{H}_{9} \text { or } \mathrm{C}_{6} \mathrm{H}_{13}\right)
$$

Scheme 1. Structural formulae of alkoxyethanol compounds used in this work.

\section{Results and Discussion}

\subsection{Crystal Structure}

Single crystals of the complexes I-III were prepared by a method similar to the literature procedure [1]. Crystal data for I-III are listed in Table 1. In the three complexes, all cyanides bridge between two $\mathrm{Cd}$ (II) ions, and $\mathrm{Cd}(\mathrm{CN})_{2}$ consists of a three-dimensional framework with large cavities (Figures 1-3). From IR spectra, the peaks of $C \equiv N$ stretching $\left(v_{\mathrm{CN}}\right)$ were observed at $2185-2190 \mathrm{~cm}^{-1}$. The $v_{\mathrm{CN}}$ values showed a blue shift from that which was observed for terminal $\mathrm{C} \equiv \mathrm{N}$ of $\mathrm{K}_{2}\left[\mathrm{Cd}(\mathrm{CN})_{2}\right]$ $\left(2145 \mathrm{~cm}^{-1}\right)$, supporting a view that the $\mathrm{C} \equiv \mathrm{N}$ bridged between two $\mathrm{Cd}(\mathrm{II})$ ions. The exact arrangements of cyanides ( $\mathrm{Cd}-\mathrm{NC}-\mathrm{Cd}$ or $\mathrm{Cd}-\mathrm{CN}-\mathrm{Cd}$ ) cannot be determined by single $\mathrm{X}$-ray diffraction because these arrangements are disordered. Nishikiori et al. $[6,12,13]$ show that arrangements of cyanides in $\mathrm{Cd}(\mathrm{CN})_{2}$ host are disordered by ${ }^{113} \mathrm{Cd}-\mathrm{CP} / \mathrm{MAS} \mathrm{NMR}$.

Table 1. Crystal Data for I, II and III.

\begin{tabular}{|c|c|c|c|}
\hline Complex & I & II & III \\
\hline Empirical formula & $\mathrm{C}_{6} \mathrm{H}_{10} \mathrm{CdN}_{2} \mathrm{O}_{2}$ & $\mathrm{C}_{26} \mathrm{H}_{42} \mathrm{Cd}_{4} \mathrm{~N}_{8} \mathrm{O}_{6}$ & $\mathrm{C}_{24} \mathrm{H}_{40} \mathrm{Cd}_{4} \mathrm{~N}_{8} \mathrm{O}_{6}$ \\
\hline Formula weight & 254.56 & 1012.28 & 986.24 \\
\hline Temperature (K) & 253 & 273 & 90 \\
\hline Crystal system & Orthorhombic & Monoclinic & Orthorhombic \\
\hline Space group & $\mathrm{C} 222_{1}$ & $P 2_{1} / c$ & Pnma \\
\hline$a(\AA)$ & $8.1727(3)$ & $8.9441(4)$ & $38.0252(19)$ \\
\hline$b(\AA)$ & $15.7149(6)$ & $15.2192(7)$ & $8.7786(4)$ \\
\hline$c(\AA)$ & $15.3108(6)$ & 29.4582(13) & $12.0948(6)$ \\
\hline$\alpha\left({ }^{\circ}\right)$ & 90 & 90 & 90 \\
\hline$\beta\left(^{\circ}\right)$ & 90 & $91.6930(10)$ & 90 \\
\hline$\gamma\left({ }^{\circ}\right)$ & 90 & 90 & 90 \\
\hline$V\left(\AA^{3}\right)$ & 1966.41(13) & $4008.2(3)$ & 4037.3(3) \\
\hline Z & 8 & 4 & 4 \\
\hline$d_{\text {calc }}\left(\mathrm{g} \mathrm{cm}^{-3}\right)$ & 1.720 & 1.677 & 1.623 \\
\hline$\mu\left(\mathrm{mm}^{-1}\right)$ & 2.180 & 2.135 & 2.118 \\
\hline $\mathrm{F}(000)$ & 992 & 1976 & 1920 \\
\hline Reflections collected & 7375 & 29345 & 20635 \\
\hline$R_{\text {int }}$ & 0.0142 & 0.0228 & 0.0320 \\
\hline Data/restraints/parameters & $2909 / 0 / 115$ & $9947 / 63 / 438$ & $3823 / 343 / 320$ \\
\hline GOF & 1.030 & 1.010 & 1.181 \\
\hline$R 1, w R 2[I>2 \sigma(I)]$ & $0.0164,0.0369$ & $0.0326,0.0749$ & $0.0633,0.1312$ \\
\hline Flack parameter [14] & $0.00(3)$ & - & - \\
\hline$\Delta \rho_{\max }, \Delta \rho_{\min }\left(\mathrm{e} \AA^{-3}\right)$ & $0.327,-0.333$ & $0.501,0.688$ & $1.089,-1.559$ \\
\hline
\end{tabular}




\subsubsection{Crystal Structure of $\left[\mathrm{Cd}(\mathrm{CN})_{2}(\text { Etcel })\right]_{\mathrm{n}} \mathbf{I}$}

For complex I, crystal structure is shown in Figure 1 and selected parameters are listed in Table 2. The complex I consists of one crystallographically independent Cd(II) ion; the Cd(II) is labeled Cd1. Cd1 exhibits five-coordination (Figure 1a). Five-coordination geometry is estimated by a simple distortion parameter $\tau$. The $\tau$ parameter was proposed by Addison et al. $[15,16]$. The $\tau$ value is simply defined by $\tau=\left(\theta_{1}-\theta_{2}\right) / 60$, where $\theta_{1}$ is the largest and $\theta_{2}$ is second largest basal angle, a perfect square pyramid is characterized by $\tau=0$, while $\tau=1$ means a perfect trigonal bipyramid $[15,16]$. For the $\mathrm{Cd} 1, \tau$ is 0.82 from selected bond angles in Table 2 . Therefore, $\mathrm{Cd} 1$ is slightly distorted $\mathrm{Cd}_{\mathrm{TB}}$. Around the $\mathrm{Cd} 1$, one hydroxyl oxygen atom $\mathrm{O} 1$ of Etcel ligand is located at one of the axial positions and four cyanides are located at the remaining positions, namely, another axial position (denoted as ax) and three equatorial positions (eq). Cd1 is located in the general position. Atoms labeled C2/N2 or C3/N3 are hybrid due to the disorder of arrangement of cyanide (Figure 1a), and due to the midpoints of $\mathrm{C} \equiv \mathrm{N}$ bonds on the symmetry of the lattice [1-6,12]. The values of bond lengths around $\mathrm{Cd}(\mathrm{II})$ ions decrease in the order $\mathrm{Cd}_{\mathrm{TB}}-\mathrm{O}>\mathrm{Cd}_{\mathrm{TB}}-(\mathrm{CN})_{\mathrm{ax}}>\mathrm{Cd}_{\mathrm{TB}}-(\mathrm{CN})_{\mathrm{eq}}$ (Table 2). $\mathrm{Cd}(\mathrm{CN})_{2}$ framework is distorted-tridymite-like structure, and the cavities' shape is distorted $\left[6^{5}\right]$ $\mathbf{t}$-afi tile $[17,18]$. The cavities of $\mathrm{Cd}(\mathrm{CN})_{2}$ network are occupied by the Etcel ligands (Figure $1 \mathrm{~b}, \mathrm{c}$ ). Etcel ligand dose not protrude from one cavity. The Etcel ligand is connected with the neighboring Etcel by hydrogen bonds between one ligand's hydroxyl oxygen atom $\mathrm{O} 1$ and the other's etheric oxygen atom O2 (Figure 1c and Table 2). In thermogravimetric analysis (TGA) for I (Figure S1), thermogravimetric (TG) and differential thermogravimetric (DTG) curves showed one-step weight loss in the range from about $100^{\circ} \mathrm{C}$ to $155^{\circ} \mathrm{C}$. This supported the proposition that the Etcel ligand is crystallographically independent as shown in Figure 1a, and that the $\mathrm{Cd}(\mathrm{CN})_{2}$ cavity is uniformity as shown in Figure 1b. The absolute values of torsion angles of ethyleneglycol fragment $\left(\mathrm{O}-\mathrm{CH}_{2}-\mathrm{CH}_{2}-\mathrm{O}\right)$ are values close to $60^{\circ}$ (Table 2). Thus, the conformation of the ethyleneglycol fragment in Etcel ligand is gauche form. As a result, $\left(\mathrm{O}-\mathrm{CH}_{2}-\mathrm{CH}_{2}-\mathrm{O}\right)_{2}$ eight-membered ring is constructed by the two ethyleneglycol fragments. The carbon atom (C11 or $\left.\mathrm{C}^{\prime} 1^{\prime}\right)$ binding with hydroxyl oxygen atom is disordered (Figure 1a).

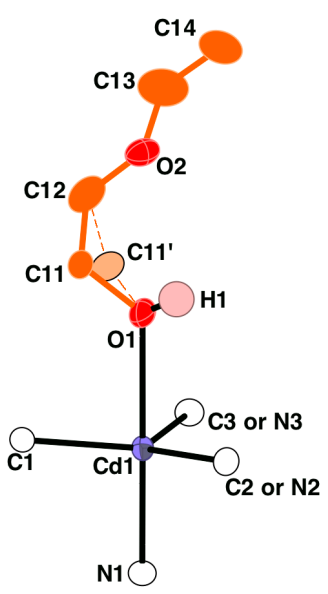

(a)

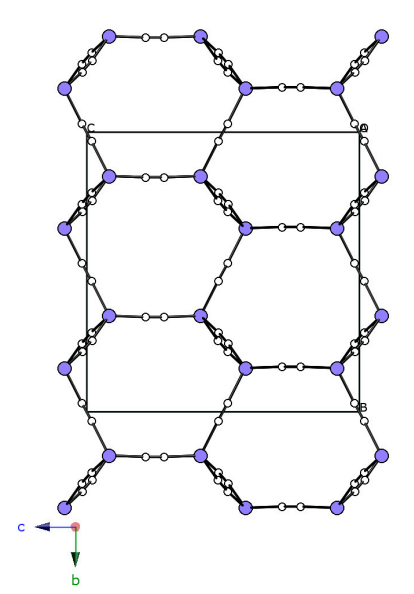

(b)

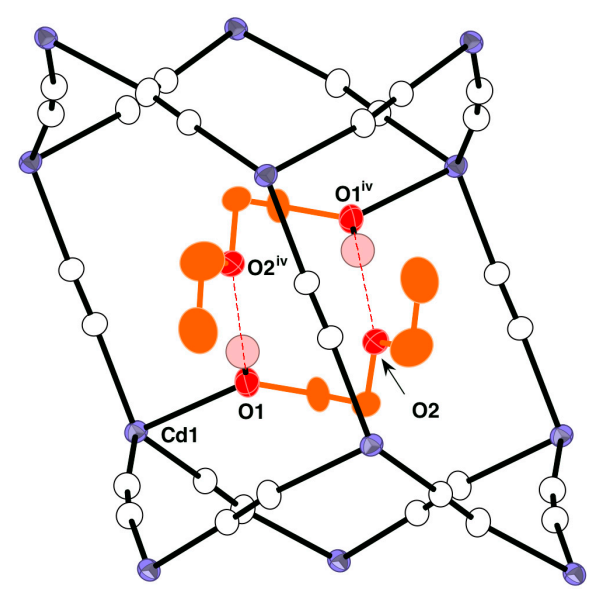

(c)

Figure 1. Crystal structure of $\mathbf{I}$. $\mathrm{H}$ atoms except $\mathrm{OH}$ hydrogens are omitted for clarity: (a) Asymmetric unit. Displacement ellipsoids are drawn at the $30 \%$ probability level. Because arrangements of cyanides $(\mathrm{Cd}-\mathrm{NC}-\mathrm{Cd}$ or $\mathrm{Cd}-\mathrm{CN}-\mathrm{Cd})$ are disordered, the atoms of cyanide are labeled less clearly; (b) The $\mathrm{Cd}(\mathrm{CN})_{2}$ network structure view along the $a$ axis; (c) Hydrogen bonds between neighboring Etcel ligands in cavities of distorted-tridymite-like cadmium cyanide network of I. Displacement ellipsoids are drawn at the $30 \%$ probability level. The disorder part is omitted for clarity. (Symmetry codes: iv $=-x+1, y,-z+3 / 2$ ). 
Table 2. Selected Parameters for I.

\begin{tabular}{|c|c|}
\hline \multicolumn{2}{|l|}{$\mathrm{Cd}_{\mathrm{TB}}-\mathrm{O} / \AA$} \\
\hline Cd1-O1 & $2.5207(19)$ \\
\hline \multicolumn{2}{|l|}{$\mathrm{Cd}_{\mathrm{TB}}-(\mathrm{CN})_{\mathrm{ax}} / \AA$} \\
\hline Cd1-N1 & $2.3449(19)$ \\
\hline \multicolumn{2}{|l|}{$\mathrm{Cd}_{\mathrm{TB}}-(\mathrm{CN})_{\mathrm{eq}} / \AA$} \\
\hline $\mathrm{Cd} 1-\mathrm{C} 1$ & $2.197(2)$ \\
\hline $\mathrm{Cd} 1-\mathrm{N} 2$ & $2.2060(18)$ \\
\hline $\mathrm{Cd} 1-\mathrm{N} 3$ & $2.210(2)$ \\
\hline \multicolumn{2}{|l|}{$(\mathrm{CN})-(\mathrm{CN}) / \AA$} \\
\hline $\mathrm{N} 1-\mathrm{C}^{\mathrm{i}}$ & $1.135(3)$ \\
\hline $\mathrm{N} 2-\mathrm{C} 2^{\mathrm{ii}}$ & $1.141(4)$ \\
\hline N3-C $3^{\text {iii }}$ & $1.135(4)$ \\
\hline \multicolumn{2}{|c|}{$(\mathrm{CN})_{\mathrm{eq}}-\mathrm{Cd}_{\mathrm{TB}}-(\mathrm{CN})_{\mathrm{eq}} /{ }^{\circ}$} \\
\hline $\mathrm{C} 1-\mathrm{Cd} 1-\mathrm{N} 2$ & $128.65(8)$ \\
\hline $\mathrm{C} 1-\mathrm{Cd} 1-\mathrm{N} 3$ & $116.08(8)$ \\
\hline N2-Cd1-N3 & $113.44(8)$ \\
\hline \multicolumn{2}{|c|}{$(\mathrm{CN})_{\mathrm{ax}}-\mathrm{Cd}_{\mathrm{TB}}-(\mathrm{CN})_{\mathrm{eq}} /{ }^{\circ}$} \\
\hline N1-Cd1-C1 & $95.06(7)$ \\
\hline N1-Cd1-N2 & $94.67(7)$ \\
\hline N1-Cd1-N3 & $93.53(7)$ \\
\hline \multicolumn{2}{|l|}{$(\mathrm{CN})_{\mathrm{ax}}-\mathrm{Cd}_{\mathrm{TB}}-\mathrm{O} /{ }^{\circ}$} \\
\hline N1-Cd1-O1 & $177.94(7)$ \\
\hline \multicolumn{2}{|l|}{$(\mathrm{CN})_{\mathrm{eq}}-\mathrm{Cd}_{\mathrm{TB}}-\mathrm{O} /{ }^{\circ}$} \\
\hline $\mathrm{C} 1-\mathrm{Cd} 1-\mathrm{O} 1$ & $84.83(7)$ \\
\hline N2-Cd1-O1 & $86.99(7)$ \\
\hline N3-Cd1-O1 & $84.67(7)$ \\
\hline Hydrogen bond $/ \AA$ & \\
\hline $\begin{array}{c}\mathrm{O} 1 \cdots \mathrm{O} 2^{\mathrm{iv}} \\
\text { torsion angle } /^{\circ}\end{array}$ & $2.774(2)$ \\
\hline $\mathrm{O} 1-\mathrm{C} 11-\mathrm{C} 12-\mathrm{O} 2$ & $-68.6(4)$ \\
\hline $\mathrm{O} 1-\mathrm{C} 11^{\prime}-\mathrm{C} 12-\mathrm{O} 2$ & $54.1(9)$ \\
\hline
\end{tabular}

Symmetry codes: $\mathrm{i}=x-\overline{1 / 2,-y+3 / 2,-z+1 \text {; ii }=-x, y,-z+3 / 2 ; \text { iii }=x,-y+1},-z+1$; iv $=-x+1, y$, $-z+3 / 2$

\subsubsection{Crystal Structure of $\left[\left\{\mathrm{Cd}(\mathrm{CN})_{2}(\text { Bucel })\right\}_{3}\left\{\mathrm{Cd}(\mathrm{CN})_{2}\right\}\right]_{\mathrm{n}}$ II}

For complex II, crystal structure is shown in Figure 2 and selected parameters are listed in Table 3. The complex II contains two distinct coordination geometric $\mathrm{Cd}(\mathrm{II})$ ions; the one slightly distorted $\mathrm{Cd}_{\mathrm{TB}}(\mathrm{Cd} 1(\tau=0.76), \mathrm{Cd} 2(\tau=0.87)$ and $\mathrm{Cd} 3(\tau=0.82)($ from Table 3$))[15,16]$ and the other $\mathrm{Cd}_{\mathrm{T}}(\mathrm{Cd} 4)$ in a ratio of 3:1 (Figure 2a). Around the $\mathrm{Cd}_{\mathrm{TB}}$, one hydroxyl oxygen atom of Bucel ligand is located at one of the axial positions and four cyanides are located at the remaining positions. $\mathrm{Cd}_{\mathrm{T}}$ is coordinated by only four cyanides. All Cd(II) ions are located on the general positions. The values of bond lengths around $\mathrm{Cd}(\mathrm{II})$ ions decrease in the order $\mathrm{Cd}_{\mathrm{TB}}-\mathrm{O}>\mathrm{Cd}_{\mathrm{TB}}-(\mathrm{CN})_{\mathrm{ax}}>\mathrm{Cd}_{\mathrm{TB}}-(\mathrm{CN})_{\mathrm{eq}} \approx \mathrm{Cd}_{\mathrm{T}}-(\mathrm{CN})$ (Table 3). This tendency is similar to $\mathrm{I}$ and $\mathrm{Cd}_{5}(\mathrm{CN})_{10}\left(\mathrm{H}_{2} \mathrm{O}\right)_{4} \cdot 4 \mathrm{C}_{6} \mathrm{H}_{11} \mathrm{OH}$ [6]. The $\mathrm{Cd}(\mathrm{CN})_{2}$ framework forms zeolite-like structure and three kinds of cavities. These cavities' shapes are distorted $\left[6^{5}\right] \mathbf{t}$-afi, distorted $\left[6^{2} .8^{2}\right] \mathbf{t}$-kaa and distorted $\left[4^{2} .6^{4}\right] \mathbf{t}$-lau tiles $[17,18]$, respectively (Figure $2 \mathrm{~b}-\mathrm{d}$ ). To our knowledge, zeolite constructed by the three tiles are not reported and the framework topology is new $[17,18]$. The all cavities of $\mathrm{Cd}(\mathrm{CN})_{2}$ network are occupied by the Bucel ligands, but the terminals of the butyl groups protrude from one cavity (Figure 2d). This is suggested below; Bucel does not coordinate to one of four $\mathrm{Cd}$ (II) ions because total volume of Bucel coordinating to four of four $\mathrm{Cd}$ (II) ions exceeds the capacity of the total cavity of the $\mathrm{Cd}(\mathrm{CN})_{2}$ network. In the $\mathbf{t}$-afi and $\mathbf{t}$-kaa cavities, the Bucel ligand is connected with the neighboring Bucel by hydrogen bonds between one ligand's hydroxyl oxygen atom and the other's etheric oxygen atom (Figure $2 \mathrm{~d}$ and Table 3 ) as case of I. Conformations of ethyleneglycol fragments of Bucel ligands are gauche form (Table 3). In TGA for II (Figure S2), TG and DTG curves showed three-steps weight loss in the range of about $100{ }^{\circ} \mathrm{C}$ to $180^{\circ} \mathrm{C}$. This suggests 
that one Bucel ligand was removed from the complex II having three kind of cavities (Figure $2 \mathrm{~b}-\mathrm{d}$ ) per one-step. In Bucel ligands, part of butyl groups and of the ethylene groups are disordered. In contrast, because etheric oxygen atoms $(\mathrm{O} 2, \mathrm{O} 4$ and $\mathrm{O} 6)$ of the Bucel ligand connect hydroxyl oxygen atoms (O3, O1 and $\mathrm{O} 5)$ of the neighboring Bucel by hydrogen bond, etheric oxygen atoms are in a more strongly fixed position than the butyl groups' atoms and have small anisotropic parameters.

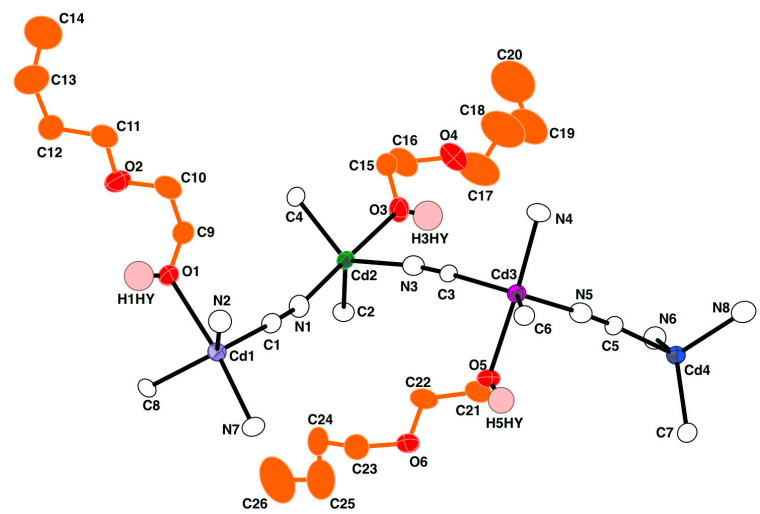

(a)
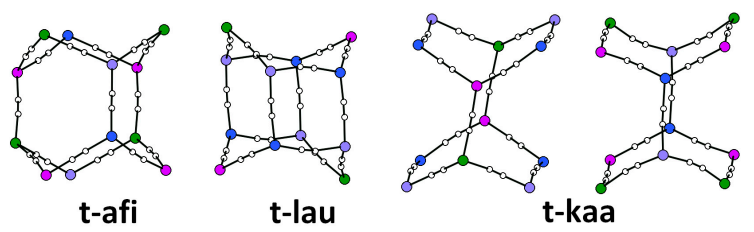

(c)

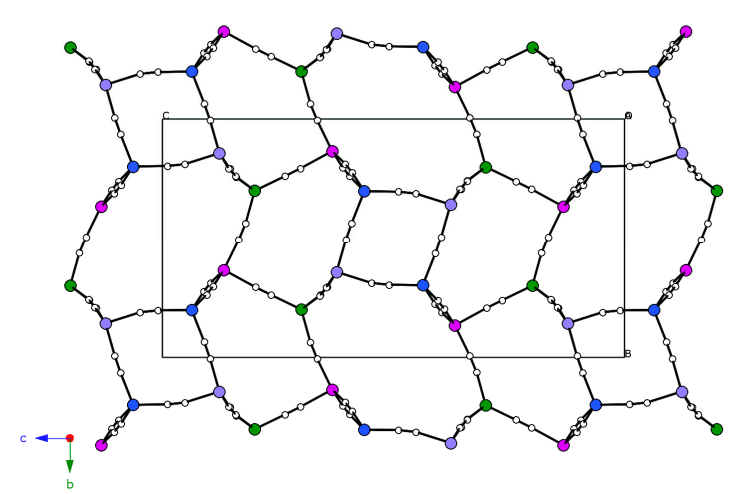

(b)

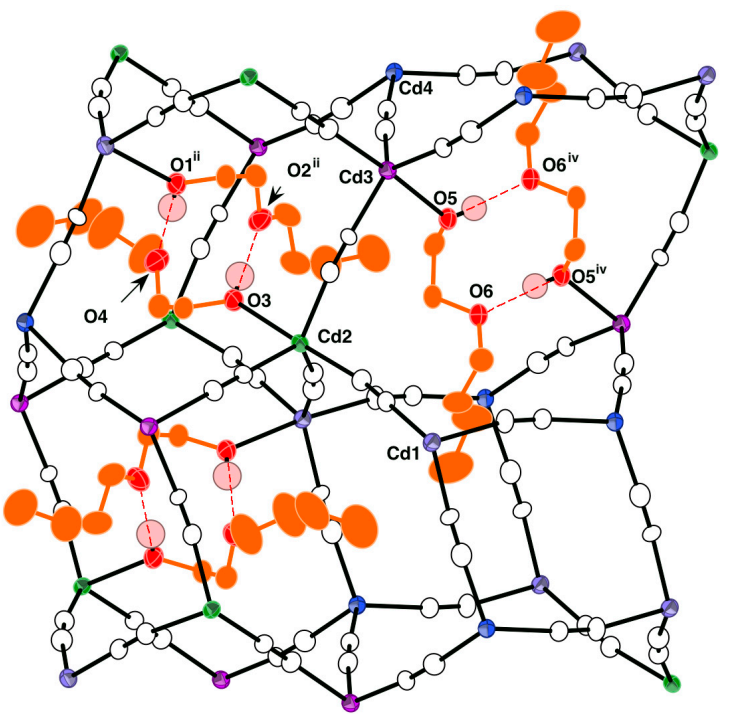

(d)

Figure 2. Crystal structure of II. $\mathrm{H}$ atoms except $\mathrm{OH}$ hydrogens and disorder parts are omitted for clarity: (a) Asymmetric unit. Displacement ellipsoids are drawn at the $30 \%$ probability level. Because arrangements of cyanides $(\mathrm{Cd}-\mathrm{NC}-\mathrm{Cd}$ or $\mathrm{Cd}-\mathrm{CN}-\mathrm{Cd})$ are disordered, the atoms of cyanide are labeled less clearly; (b) The $\mathrm{Cd}(\mathrm{CN})_{2}$ network structure of the view along the $a$ axis; (c) $\left[6^{5}\right] \mathbf{t}$-afi, $\left[4^{2} .6^{4}\right] \mathrm{t}$-lau and $\left[6^{2} .8^{2}\right] \mathrm{t}$-kaa tiles; (d) Hydrogen bonds between neighboring Bucel ligands in cavities of cadmium cyanide network of II. Displacement ellipsoids are drawn the $30 \%$ probability level. (Symmetry codes: $\mathrm{ii}=-x+1, y-1 / 2,-z+1 / 2$; iv $=-x+1,-y+1,-z$ ). 
Table 3. Selected Parameters for II.

\begin{tabular}{|c|c|c|c|c|c|}
\hline $\mathrm{Cd}_{\mathrm{TB}}-\mathrm{O} / \AA$ & & & & & \\
\hline Cd1-O1 & $2.530(3)$ & $\mathrm{Cd} 2-\mathrm{O} 3$ & $2.547(3)$ & $\mathrm{Cd} 3-\mathrm{O} 5$ & $2.480(2)$ \\
\hline \multicolumn{6}{|l|}{$\mathrm{Cd}_{\mathrm{TB}}-(\mathrm{CN})_{\mathrm{ax}} / \AA$} \\
\hline Cd1-N7 & $2.322(3)$ & $\mathrm{Cd} 2-\mathrm{N} 1$ & $2.323(3)$ & $\mathrm{Cd} 3-\mathrm{N} 4$ & $2.303(3)$ \\
\hline \multicolumn{6}{|l|}{$\mathrm{Cd}_{\mathrm{TB}}-(\mathrm{CN})_{\mathrm{eq}} / \AA$} \\
\hline $\mathrm{Cd} 1-\mathrm{C} 1$ & $2.200(3)$ & $\mathrm{Cd} 2-\mathrm{C} 2$ & $2.182(3)$ & $\mathrm{Cd} 3-\mathrm{C} 3$ & $2.190(3)$ \\
\hline $\mathrm{Cd} 1-\mathrm{C} 8$ & $2.185(3)$ & $\mathrm{Cd} 2-\mathrm{C} 4$ & $2.194(3)$ & $\mathrm{Cd} 3-\mathrm{C} 6$ & $2.180(3)$ \\
\hline $\mathrm{Cd} 1-\mathrm{N} 2$ & $2.218(3)$ & $\mathrm{Cd} 2-\mathrm{N} 3$ & $2.212(3)$ & Cd3-N5 & $2.223(3)$ \\
\hline \multicolumn{6}{|l|}{$\mathrm{Cd}_{\mathrm{T}}-(\mathrm{CN}) / \AA$} \\
\hline $\mathrm{Cd} 4-\mathrm{C} 5$ & $2.203(3)$ & Cd4-N6 & $2.229(3)$ & & \\
\hline $\mathrm{Cd} 4-\mathrm{C} 7$ & $2.176(3)$ & $\mathrm{Cd} 4-\mathrm{N} 8$ & $2.215(4)$ & & \\
\hline \multicolumn{6}{|l|}{$(\mathrm{CN})-(\mathrm{CN}) / \AA$} \\
\hline $\mathrm{N} 1-\mathrm{C} 1$ & $1.123(4)$ & $\mathrm{N} 2-\mathrm{C}^{\mathrm{i}}$ & $1.136(4)$ & N3-C3 & $1.140(4)$ \\
\hline $\mathrm{N} 4-\mathrm{C} 4^{\mathrm{ii}}$ & $1.130(4)$ & N5-C5 & $1.140(4)$ & N6-C6 $6^{\text {iii }}$ & $1.137(4)$ \\
\hline $\mathrm{N} 7-\mathrm{C}^{\mathrm{iv}}$ & $1.125(4)$ & $\mathrm{N} 8-\mathrm{C} 8^{\mathrm{v}}$ & $1.137(5)$ & & \\
\hline \multicolumn{6}{|l|}{$(\mathrm{CN})_{\mathrm{ax}}-\mathrm{Cd}_{\mathrm{TB}}-\mathrm{O} /{ }^{\circ}$} \\
\hline \multirow{2}{*}{\multicolumn{6}{|c|}{$(\mathrm{CN})_{\mathrm{eq}}-\mathrm{Cd}_{\mathrm{TB}}-\mathrm{O} /{ }^{\circ}$}} \\
\hline & & & & & \\
\hline C1-Cd1-O1 & $85.07(10)$ & $\mathrm{C} 2-\mathrm{Cd} 2-\mathrm{O} 3$ & $83.78(12)$ & $\mathrm{C} 3-\mathrm{Cd} 3-\mathrm{O} 5$ & $83.28(10)$ \\
\hline $\mathrm{C} 8-\mathrm{Cd} 1-\mathrm{O} 1$ & $82.64(11)$ & $\mathrm{C} 4-\mathrm{Cd} 2-\mathrm{O} 3$ & $84.57(11)$ & C6-Cd3-O5 & 87.31(10) \\
\hline N2-Cd1-O1 & $85.01(11)$ & N3-Cd2-O3 & $84.01(10)$ & N5-Cd3-O5 & $85.06(10)$ \\
\hline \multicolumn{6}{|c|}{$(\mathrm{CN})_{\mathrm{eq}}-\mathrm{Cd}_{\mathrm{TB}}-(\mathrm{CN})_{\mathrm{ax}} /^{\circ}$} \\
\hline C1-Cd1-N7 & $99.90(11)$ & $\mathrm{C} 2-\mathrm{Cd} 2-\mathrm{N} 1$ & $97.20(12)$ & $\mathrm{C} 3-\mathrm{Cd} 3-\mathrm{N} 4$ & $93.05(11)$ \\
\hline C8-Cd1-N7 & $91.44(12)$ & $\mathrm{C} 4-\mathrm{Cd} 2-\mathrm{N} 1$ & $96.41(11)$ & $\mathrm{C} 6-\mathrm{Cd} 3-\mathrm{N} 4$ & $95.48(11)$ \\
\hline $\mathrm{N} 2-\mathrm{Cd} 1-\mathrm{N} 7$ & $95.90(12)$ & $\mathrm{N} 3-\mathrm{Cd} 2-\mathrm{N} 1$ & $94.06(11)$ & N5-Cd3-N4 & $96.03(11)$ \\
\hline \multicolumn{6}{|c|}{$(\mathrm{CN})_{\mathrm{eq}}-\mathrm{Cd}_{\mathrm{TB}}-(\mathrm{CN})_{\mathrm{eq}} /{ }^{\circ}$} \\
\hline $\mathrm{C} 8-\mathrm{Cd} 1-\mathrm{C} 1$ & $128.24(13)$ & $\mathrm{C} 2-\mathrm{Cd} 2-\mathrm{C} 4$ & $117.75(13)$ & $\mathrm{C} 6-\mathrm{Cd} 3-\mathrm{C} 3$ & $126.97(12)$ \\
\hline $\mathrm{C} 1-\mathrm{Cd} 1-\mathrm{N} 2$ & $116.09(13)$ & $\mathrm{C} 2-\mathrm{Cd} 2-\mathrm{N} 3$ & $113.13(12)$ & C3-Cd3-N5 & $117.07(12)$ \\
\hline C8-Cd1-N2 & $112.61(12)$ & $\mathrm{C} 4-\mathrm{Cd} 2-\mathrm{N} 3$ & $126.01(12)$ & $\mathrm{C} 6-\mathrm{Cd} 3-\mathrm{N} 5$ & $113.87(12)$ \\
\hline \multicolumn{6}{|l|}{$(\mathrm{CN})-\mathrm{Cd}_{\mathrm{T}}-(\mathrm{CN}) /{ }^{\circ}$} \\
\hline $\mathrm{C} 7-\mathrm{Cd} 4-\mathrm{C} 5$ & $110.76(12)$ & $\mathrm{C} 7-\mathrm{Cd} 4-\mathrm{N} 6$ & $115.46(13)$ & $\mathrm{C} 7-\mathrm{Cd} 4-\mathrm{N} 8$ & $111.38(13)$ \\
\hline C5-Cd4-N6 & 103.02(12) & $\mathrm{C} 5-\mathrm{Cd} 4-\mathrm{N} 8$ & $110.93(12)$ & N8-Cd4-N6 & $104.89(12)$ \\
\hline \multicolumn{6}{|l|}{ Hydrogen bond/ $\AA$} \\
\hline $\mathrm{O} 1 \cdots \mathrm{O} 4^{\mathrm{vi}}$ & $2.763(4)$ & $\mathrm{O} 3 \cdots \mathrm{O} 2^{\mathrm{ii}}$ & $2.777(4)$ & $\mathrm{O} 5 \cdots \mathrm{O}^{\mathrm{iv}}$ & $2.708(3)$ \\
\hline torsion angle ${ }^{\circ}$ & & & & & \\
\hline O1-C9-C10-O2 & $-69.5(7)$ & $\mathrm{O} 1-\mathrm{C} 9^{\prime}-\mathrm{C} 10-\mathrm{O} 2$ & $44.6(19)$ & & \\
\hline O3-C15-C16-O4 & $-71.5(6)$ & $\mathrm{O} 3-\mathrm{C} 15^{\prime}-\mathrm{C} 16-\mathrm{O} 4$ & $42(2)$ & & \\
\hline O5-C21-C22-O6 & $-74.2(4)$ & & & & \\
\hline
\end{tabular}

Symmetry codes: $\mathrm{i}=x-1, y, z ; \mathrm{ii}=-x+1, y-1 / 2,-z+1 / 2 ; \mathrm{iii}=x+1, y, z ; \mathrm{iv}=-x+1,-y+1,-z ; \mathrm{v}=x+1$, $y-1, z ; \mathrm{vi}=-x+1, y+1 / 2,-z+\frac{1}{2}$.

\subsubsection{Crystal Structure of $\left[\left\{\mathrm{Cd}(\mathrm{CN})_{2}\left(\mathrm{H}_{2} \mathrm{O}\right)_{2}\right\}\left\{\mathrm{Cd}(\mathrm{CN})_{2}\right\}_{3} \cdot 2(\text { Hexcel })\right]_{n}$ III}

For complex III, the crystal structure is shown in Figure 3 and selected parameters are listed in Table 4. The complex III contains two distinct coordination geometry $\mathrm{Cd}(\mathrm{II})$ ions; the one $\mathrm{Cd} \mathrm{OC}_{\mathrm{OC}}$ (Cd1) and the other $\mathrm{Cd}_{\mathrm{T}}(\mathrm{Cd} 2, \mathrm{Cd} 3$ and $\mathrm{Cd} 4)$ in a ratio of 1:3 (Figure 3a). All $\mathrm{Cd}(\mathrm{II})$ ions lie on mirror plane in the cell. Around the $\mathrm{Cd}_{\mathrm{OC}}$, two oxygen atoms of water molecules are located at the cis-positions (Figure 3d) and four cyanides are located at the remaining positions. The water molecule (O1 or O11) is disordered (Figure 3a,d). The difference between the bond lengths of Cd1-O1 and Cd1-O11 (Table 4) indicates that the water molecule's position is not constant. $\mathrm{Cd}_{\mathrm{T}}$ is coordinated by four cyanides. The values of bond lengths around $\mathrm{Cd}(\mathrm{II})$ ions decrease in the order $\mathrm{Cd}_{\mathrm{OC}}-\mathrm{O} \approx \mathrm{Cd}_{\mathrm{OC}}-(\mathrm{CN}) \approx \mathrm{Cd}_{\mathrm{T}}-(\mathrm{CN})$ (Table 4). The $\mathrm{Cd}_{\mathrm{OC}}-\mathrm{O}$ bond of III (Table 4) is shorter than $\mathrm{Cd}_{\mathrm{TB}}-\mathrm{O}$ bonds of I and II (Tables 2 and 3). The $\mathrm{Cd}(\mathrm{CN})_{2}$ framework forms zeolite-like structure and two kind of cavities. These cavities' shape are distorted $\left[6^{4}\right] \mathbf{t}$-hes and distorted $\left[4^{2} \cdot 6^{2} \cdot 8^{2}\right] \mathbf{t}-\mathbf{k d q}$ tiles ${ }^{17}$, respectively (Figure 3b,c). The fragment of distorted $\mathbf{t}-\mathbf{k d q}$ tile is similar to $\mathrm{Cd}(\mathrm{CN})_{2}$ framework for $\mathrm{Cd}(\mathrm{CN})_{2}\left(\mathrm{H}_{2} \mathrm{O}\right) \cdot \mathrm{dmf}[8]$. JBW $[17,18]$ zeolite constructed by the above two tiles are reported. 
However, the III contains more t-hes tile than JBW. To our knowledge, the framework topology is new $[17,18]$. The Hexcel molecule does not coordinate to $\mathrm{Cd}(\mathrm{II})$ ion, and the hydroxyl oxygen atom connects the water molecule through weak hydrogen bond in the $\mathbf{t}-\mathbf{k d q}$ cavity (Figure 3 and Table 4). In the Hexcel molecule, Weak $\mathrm{C}-\mathrm{H} \cdots \mathrm{O}$ interaction is observed (Table 4). Two crystallographically independent Hexcel molecules exist in the crystal. TG and DTG curves (Figure S3) were observed in three steps of weight loss ranging from about $40{ }^{\circ} \mathrm{C}$ to $75{ }^{\circ} \mathrm{C}$, from $80{ }^{\circ} \mathrm{C}$ to $205{ }^{\circ} \mathrm{C}$, and from $205^{\circ} \mathrm{C}$ to $230^{\circ} \mathrm{C}$. The first weight loss seems to trigger desorption of Hexcel molecules at the second weight loss [19]. The third weight loss seems to involve elimination of water ligands. The Hexcel molecules' atoms are disordered. In addition, because Hexcel molecules lie on the mirror plane for the cell (Figure $3 \mathrm{a}, \mathrm{d}$ ), the atoms are almost disordered to symmetrically mirror themselves.

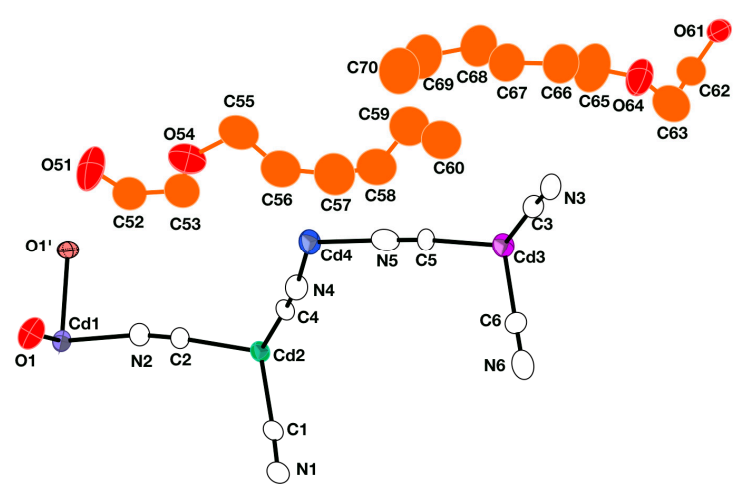

(a)

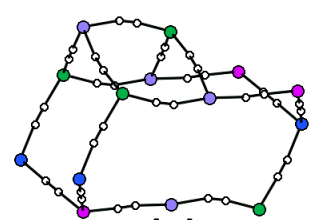

t-kdq

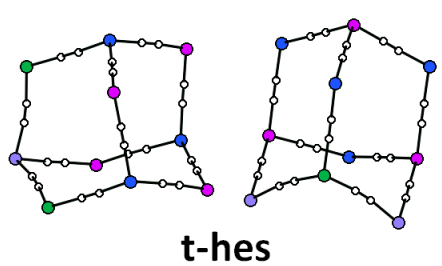

t-hes

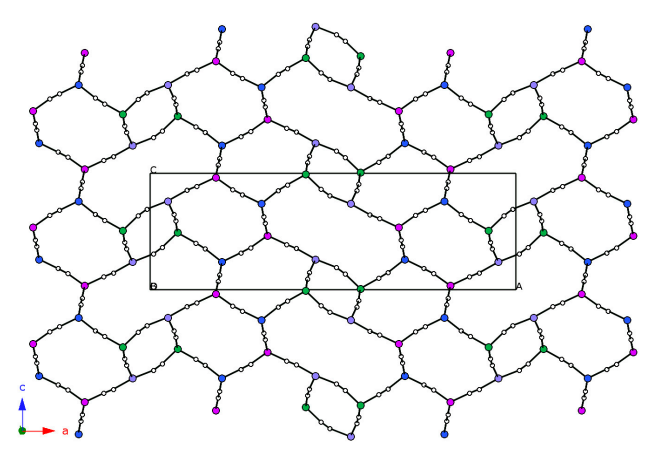

(b)

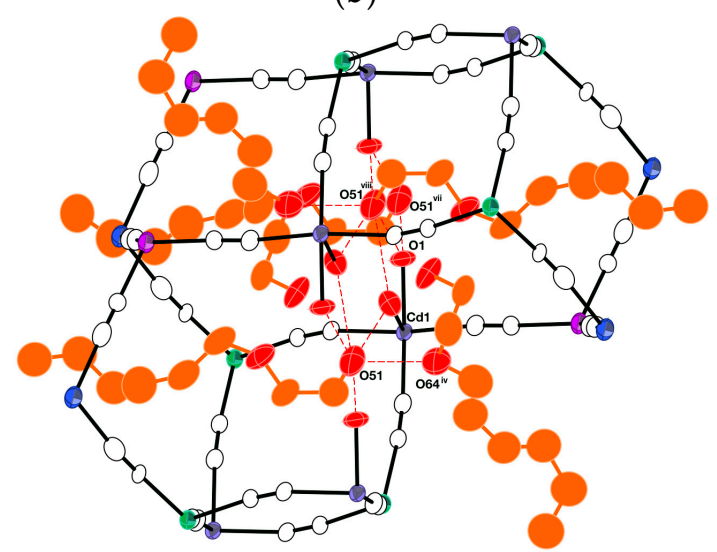

(d)

Figure 3. Crystal structure of III. H atoms and disorder parts are omitted for clarity: (a) Asymmetric unit of III. Displacement ellipsoids are drawn at the $30 \%$ probability level. Because arrangements of cyanides (Cd-NC-Cd or Cd-CN-Cd) are disordered, the atoms of cyanide are labeled less clearly; (b) The $\mathrm{Cd}(\mathrm{CN})_{2}$ network structure of III along the $b$ axis; (c) $\left[6^{4}\right] \mathbf{t}$-hes and $\left[4^{2} \cdot 6^{2} \cdot 8^{2}\right] \mathbf{t}$-kdq tiles; (d) Hydrogen bonds between Hexcel and water molecules in cavities of cadmium cyanide network. Displacement ellipsoids are drawn at the $30 \%$ probability level. (symmetry codes: iv $=x+1 / 2, y$, $-z+3 / 2$; vii $=x, y-1, z$; viii $=-x+1,-y+1,-z+1)$. 
Table 4. Selected Parameters for III.

\begin{tabular}{|c|c|c|c|c|c|}
\hline $\mathrm{Cd}_{\mathrm{OC}}-\mathrm{O} / \AA$ & & & & & \\
\hline Cd1-O1 & $2.274(12)$ & $\mathrm{Cd} 1-\mathrm{O} 1^{\prime}$ & $2.49(2)$ & & \\
\hline \multicolumn{6}{|l|}{$\mathrm{Cd}_{\mathrm{OC}}-(\mathrm{CN}) / \AA$} \\
\hline $\mathrm{Cd} 1-\mathrm{N} 1^{\mathrm{i}}$ & $2.267(8)$ & $\mathrm{Cd} 1-\mathrm{N} 2$ & $2.306(10)$ & & \\
\hline $\mathrm{Cd} 1-\mathrm{N} 1^{\mathrm{ii}}$ & $2.267(8)$ & $\mathrm{Cd} 1-\mathrm{N} 3^{\mathrm{iv}}$ & $2.285(11)$ & & \\
\hline \multicolumn{6}{|l|}{$\mathrm{Cd}_{\mathrm{T}}-(\mathrm{CN}) / \AA$} \\
\hline $\mathrm{Cd} 2-\mathrm{C} 1$ & $2.191(9)$ & $\mathrm{Cd} 3-\mathrm{C} 3$ & $2.157(13)$ & $\mathrm{Cd} 4-\mathrm{N} 4$ & $2.221(15)$ \\
\hline $\mathrm{Cd} 2-\mathrm{C}^{\mathrm{iii}}$ & 2.191(9) & $\mathrm{Cd} 3-\mathrm{C} 5$ & $2.157(11)$ & Cd4-N5 & $2.179(13)$ \\
\hline $\mathrm{Cd} 2-\mathrm{C} 2$ & $2.221(12)$ & $\mathrm{Cd} 3-\mathrm{C} 6$ & $2.151(10)$ & $\mathrm{Cd} 4-\mathrm{N} 6^{\mathrm{V}}$ & $2.230(11)$ \\
\hline $\mathrm{Cd} 2-\mathrm{C} 4$ & $2.184(12)$ & $\mathrm{Cd} 3-\mathrm{C}^{\mathrm{iii}}$ & $2.151(10)$ & $\mathrm{Cd} 4-\mathrm{N} 6^{\mathrm{vi}}$ & $2.230(11)$ \\
\hline \multicolumn{6}{|l|}{$(\mathrm{CN})-(\mathrm{CN}) / \AA$} \\
\hline N1-C1 & $1.148(11)$ & N3-C3 & $1.128(15)$ & N5-C5 & $1.162(15)$ \\
\hline N2-C2 & $1.124(14)$ & $\mathrm{N} 4-\mathrm{C} 4$ & $1.146(16)$ & N6-C6 & $1.152(12)$ \\
\hline \multicolumn{6}{|l|}{$\mathrm{O}-\mathrm{Cd}_{\mathrm{OC}}-\mathrm{O} /{ }^{\circ}$} \\
\hline O1-Cd1-O1' & $87(2)$ & & & & \\
\hline \multicolumn{6}{|l|}{$(\mathrm{CN})-\mathrm{Cd}_{\mathrm{OC}}-\mathrm{O} /{ }^{\circ}$} \\
\hline $\mathrm{N} 1{ }^{\mathrm{i}}-\mathrm{Cd} 1-\mathrm{O} 1$ & $164.9(11)$ & $\mathrm{N} 3^{\mathrm{iv}}-\mathrm{Cd} 1-\mathrm{O} 1$ & $85.4(5)$ & N2-Cd1-O1' & $82.4(6)$ \\
\hline $\mathrm{N} 1{ }^{\mathrm{ii}-\mathrm{Cd} 1-\mathrm{O} 1}$ & $100.0(11)$ & $\mathrm{N} 1^{\mathrm{i}-\mathrm{Cd} 1-\mathrm{O} 1^{\prime}}$ & $78.3(12)$ & $\mathrm{N} 3^{\mathrm{iv}}-\mathrm{Cd} 1-\mathrm{O} 1^{\prime}$ & $93.0(7)$ \\
\hline N2-Cd1-O1 & $88.0(5)$ & 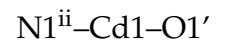 & $171.5(12)$ & & \\
\hline \multicolumn{6}{|l|}{$(\mathrm{CN})-\mathrm{Cd}_{\mathrm{OC}}-(\mathrm{CN}) /{ }^{\circ}$} \\
\hline 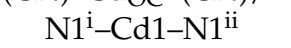 & $95.2(4)$ & 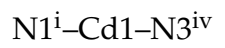 & $92.9(3)$ & & \\
\hline $\mathrm{N} 1{ }^{\mathrm{i}}-\mathrm{Cd} 1-\mathrm{N} 2$ & $92.5(2)$ & $\mathrm{N} 3^{\mathrm{iv}}-\mathrm{Cd} 1-\mathrm{N} 2$ & 172.1(4) & & \\
\hline \multicolumn{6}{|l|}{$(\mathrm{CN})-\mathrm{Cd}_{\mathrm{T}}-(\mathrm{CN}) /^{\circ}$} \\
\hline $\mathrm{C} 1-\mathrm{Cd} 2-\mathrm{C}^{\mathrm{iii}}$ & $111.2(5)$ & $\mathrm{C} 3-\mathrm{Cd} 3-\mathrm{C} 5$ & $119.5(4)$ & N5-Cd4-N4 & $115.8(4)$ \\
\hline $\mathrm{C} 1-\mathrm{Cd} 2-\mathrm{C} 2$ & $109.4(3)$ & $\mathrm{C} 6-\mathrm{Cd} 3-\mathrm{C} 3$ & $111.5(3)$ & $\mathrm{N} 4-\mathrm{Cd} 4-\mathrm{N} 6^{\mathrm{v}}$ & $106.5(3)$ \\
\hline $\mathrm{C} 4-\mathrm{Cd} 2-\mathrm{C} 1$ & $110.0(3)$ & C6-Cd3-C5 & 104.1(3) & $\mathrm{N} 5-\mathrm{Cd} 4-\mathrm{N} 6{ }^{\mathrm{v}}$ & $110.8(3)$ \\
\hline $\mathrm{C} 4-\mathrm{Cd} 2-\mathrm{C} 2$ & $106.7(4)$ & $\mathrm{C} 6-\mathrm{Cd} 3-\mathrm{C}^{\mathrm{iii}}$ & $104.9(5)$ & $\mathrm{N} 6^{\mathrm{v}}-\mathrm{Cd} 4-\mathrm{N} 6^{\mathrm{vi}}$ & $106.0(5)$ \\
\hline \multicolumn{6}{|l|}{ Hydrogen bond/ $\AA$} \\
\hline $\mathrm{O} 1 \cdots \mathrm{O} 51^{\mathrm{vii}}$ & $3.23(4)$ & O1'...O511 & $2.71(5)$ & O511 $\cdots \mathrm{O}^{\text {ix }}$ & $2.71(5)$ \\
\hline $\mathrm{O} 1 \cdots \mathrm{O} 51^{\mathrm{viii}}$ & $3.14(4)$ & $\mathrm{O} 51 \cdots \mathrm{O} 64^{\mathrm{iv}}$ & $2.66(3)$ & $\mathrm{C} 63 \cdots \mathrm{O} 61^{\mathrm{ix}}$ & $2.47(2)$ \\
\hline
\end{tabular}

\section{Materials and Methods}

\subsection{Synthesis}

\subsubsection{Synthesis for $\left[\mathrm{Cd}(\mathrm{CN})_{2} \text { (Etcel) }\right]_{\mathrm{n}} \mathbf{I}$}

An aqueous solution $(45 \mathrm{~mL})$ containing $\mathrm{CdCl}_{2} \cdot 2.5 \mathrm{H}_{2} \mathrm{O} 2 \mathrm{mmol}$ and $\mathrm{K}_{2}\left[\mathrm{Cd}(\mathrm{CN})_{4}\right] 4 \mathrm{mmol}$ was stirred for $30 \mathrm{~min}$ at room temperature. After the solution was filtered through a membrane filter, colorless crystals of I were obtained from the filtrate by vapor diffusion with Etcel in refrigerator for a few days. Elemental analysis found: $\mathrm{C} ; 27.97, \mathrm{H} ; 3.66, \mathrm{~N} ; 11.01 \%$. Calculated for $\mathrm{C}_{6} \mathrm{H}_{10} \mathrm{~N}_{2} \mathrm{O}_{2} \mathrm{Cd}$ : C; $28.31, \mathrm{H} ; 3.96, \mathrm{~N} ; 11.00 \%$. IR(nujol mull, $\left.\mathrm{cm}^{-1}\right): v_{\mathrm{OH}}=3313(\mathrm{br}), v_{\mathrm{CN}}=2186(\mathrm{~s}), v_{\mathrm{COC}}=1109(\mathrm{~s})$.

\subsubsection{Synthesis for $\left[\left\{\mathrm{Cd}(\mathrm{CN})_{2}(\text { Bucel })\right\}_{3}\left\{\mathrm{Cd}(\mathrm{CN})_{2}\right\}\right]_{\mathrm{n}}$ II}

An aqueous solution $(45 \mathrm{~mL})$ containing $\mathrm{CdCl}_{2} \cdot 2.5 \mathrm{H}_{2} \mathrm{O} 2 \mathrm{mmol}$ and $\mathrm{K}_{2}\left[\mathrm{Cd}(\mathrm{CN})_{4}\right]$ (molecular ratio; $\mathrm{CdCl}_{2} \cdot 2.5 \mathrm{H}_{2} \mathrm{O}: \mathrm{K}_{2}\left[\mathrm{Cd}(\mathrm{CN})_{4}\right]=1: 1$ or 1:2) was stirred for $30 \mathrm{~min}$ at room temperature. After the solution was filtered through a membrane filter, the filtrate was layered with Bucel. On standing at room temperature for a few days, colorless crystal of II were obtained. If the crystal was not obtained, the filtrate with Bucel was put in the refrigerator. Elemental analysis found: $\mathrm{C} ; 30.72, \mathrm{H} ; 4.10, \mathrm{~N} ; 11.17 \%$. Calculated for $\mathrm{C}_{26} \mathrm{H}_{42} \mathrm{~N}_{8} \mathrm{O}_{6} \mathrm{Cd}_{4}$ : C; 30.85, H; 4.18, N; $11.07 \%$. IR(nujol mull, $\mathrm{cm}^{-1}$ ): $v_{\mathrm{OH}}=3302(\mathrm{br})$, $v_{\mathrm{CN}}=2185(\mathrm{~s}), v_{\mathrm{COC}}=1111(\mathrm{~s})$. 


\subsubsection{Synthesis for $\left[\left\{\mathrm{Cd}(\mathrm{CN})_{2}\left(\mathrm{H}_{2} \mathrm{O}\right)_{2}\right\}\left\{\mathrm{Cd}(\mathrm{CN})_{2}\right\}_{3} \cdot 2(\mathrm{Hexcel})\right]_{\mathrm{n}}$ III}

An aqueous solution $(45 \mathrm{ml})$ containing $\mathrm{CdCl}_{2} \cdot 2.5 \mathrm{H}_{2} \mathrm{O} 2$ or 1 mmol and $\mathrm{K}_{2}\left[\mathrm{Cd}(\mathrm{CN})_{4}\right]($ molecular ratio; $\mathrm{CdCl}_{2} \cdot 2.5 \mathrm{H}_{2} \mathrm{O}: \mathrm{K}_{2}\left[\mathrm{Cd}(\mathrm{CN})_{4}\right]=1: 1$ or 1:2) were stirred for $30 \mathrm{~min}$ at room temperature. After the solution was filtered through a membrane filter, the filtrate was layered with Hexcel. On standing at room temperature for a few days, colorless crystals of III were obtained. Elemental analysis found: $\mathrm{C} ; 28.93, \mathrm{H} ; 3.92, \mathrm{~N} ; 11.30 \%$. Calculated for $\mathrm{C}_{24} \mathrm{H}_{40} \mathrm{~N}_{8} \mathrm{O}_{6} \mathrm{Cd}_{4}: \mathrm{C} ; 29.23, \mathrm{H} ; 4.09, \mathrm{~N} ; 11.36 \%$. $\mathrm{IR}\left(\right.$ nujol mull, $\left.\mathrm{cm}^{-1}\right): v_{\mathrm{OH}}=3388(\mathrm{br}), v_{\mathrm{CN}}=2190(\mathrm{~s}), v_{\mathrm{COC}}=1117(\mathrm{~s})$.

\subsection{Single Crystal X-ray Diffraction}

The structural characterization for I and III were determined by the single crystal X-ray diffraction using a BRUKER APEXII SMART CCD area-detector diffractometer (Bruker, Madison, WI, USA) with monochromated Mo-K $\alpha(\lambda=0.71073 \AA)$ under the temperature controlled $\mathrm{N}_{2}$ gas flow. The structural characterization for the II was determined by the single crystal X-ray diffraction using a BRUKER SMART CCD area-detector diffractometer (Bruker, Madison, WI, USA) with monochromated Mo-K $\alpha$ under the temperature controlled $\mathrm{N}_{2}$ gas flow. The diffraction data were treated using APEX2 [20] and SAINT ver.7.23A [21] for I and III, and using SMART [22] and SAINT ver.6.22 [23] for II. Absorption data were performed using SADABS [24]. Their structures were solved by direct method, expanded using Fourier techniques, and refined by full-matrix least-square refinement.

For I and II, H atoms for hydroxyl group were located in difference syntheses and refined isotropically. The remaining $\mathrm{H}$ atoms were placed at calculated positions, and allowed to ride on the parent atom. For II, the $\left(\begin{array}{ll}0 & 0\end{array}\right)$ reflection affected by the beamstop was omitted from the final refinement.

For III, $\mathrm{H}$ atoms for water molecules were mixed that were located in difference syntheses, and that were placed at calculated positions. The remaining $\mathrm{H}$ atoms were placed at calculated positions. All $\mathrm{H}$ atoms were allowed to ride on the parent atom. The (2 00$)$ reflection affected by the beamstop was omitted from the final refinement.

The overall structural solution was performed using SHELXTL [25]. Torsion angles and hydrogen bonds of all complexes were searched using SHELX [25] and PLATON [26]. CCDC 1472511-1472513 contain the supplementary crystallographic data for this paper. These data can be obtained free of charge via http:/ / www.ccdc.cam.ac.uk/conts/retrieving.html (or from the CCDC, 12 Union Road, Cambridge CB2 1EZ, UK; Fax: +44 1223 336033; E-mail: deposit@ccdc.cam.ac.uk).

\section{Conclusions}

We synthesized and crystallographically characterized for novel tridymite-like or zeolite-like cadmium(II) cyanide coordination polymers with alkoxyethanol; $\left[\mathrm{Cd}(\mathrm{CN})_{2}(\text { Etcel })\right]_{\mathrm{n}}$ (I), $\left[\left\{\mathrm{Cd}(\mathrm{CN})_{2}(\mathrm{Bucel})\right\}_{3}\left\{\mathrm{Cd}(\mathrm{CN})_{2}\right\}\right]_{\mathrm{n}}$ (II) and $\left[\left\{\mathrm{Cd}(\mathrm{CN})_{2}\left(\mathrm{H}_{2} \mathrm{O}\right)_{2}\right\}\left\{\mathrm{Cd}(\mathrm{CN})_{2}\right\}_{3} \cdot 2(\mathrm{Hexcel})\right]_{\mathrm{n}}$ (III). In I and II, hydroxyl oxygen atoms of alkoxyethanol molecules coordinate to the Cd(II) ions, the Cd(II) ions exhibit slightly distort trigonal-bipyramidal coordination geometry. In II, there is also tetragonal $\mathrm{Cd}(\mathrm{II})$ ion which is coordinated by only the four cyanides. On the other hand, In III, hexyloxyethanol molecules do not coordinate to the $\mathrm{Cd}$ (II) ions, and two water molecules are located at the cis-positions of octahedral Cd(II) ion.

Cadmium(II) cyanide clathrates with dialkyl-ether guests are reported that the host with short dialkyl-ether guest are $\mathrm{Cd}_{8}(\mathrm{CN})_{16}\left(\mathrm{H}_{2} \mathrm{O}\right)_{6}$ (Guest: $\mathrm{Et}_{2} \mathrm{O}$ or $\left.i-\mathrm{Pro}_{2} \mathrm{O}\right)$ or $\mathrm{Cd}_{3}(\mathrm{CN})_{6}\left(\mathrm{H}_{2} \mathrm{O}\right)_{2}$ (Guest: $\mathrm{Pro}_{2} \mathrm{O}$ ), [9] and that the host with $\mathrm{Bu}_{2} \mathrm{O}$ guest is $\mathrm{Cd}(\mathrm{CN})_{2}$ [3]. This work reveals that Etcel and Bucel molecules coordinate to $\mathrm{Cd}$ (II) ion, and that Hexcel molecule does not coordinate to $\mathrm{Cd}(\mathrm{II})$ ion. However, the Hexcel molecule may cause water molecules to coordinate to Cd(II) ion. Thus, the polar group of guest molecule may support the proposition that water molecule coordinates to $\mathrm{Cd}(\mathrm{II})$ ion in $\mathrm{Cd}(\mathrm{CN})_{2}$ network, or that the molecule itself coordinates to $\mathrm{Cd}$ (II) ion in the network. However, the lipophilic group of the guest molecule may decrease the coordination effects. From the above, it is guessed that short-alkyl alcohol molecules such as propanol coordinate to Cd(II) ion of 
$\mathrm{Cd}(\mathrm{CN})_{2}$. However, until now, it has been reported that $\mathrm{Cd}(\mathrm{II})$ ions of $\mathrm{Cd}(\mathrm{CN})_{2}$ are coordinated by not the short-alkyl alcohol molecules but water molecules $[6,7,10]$. In the case of I and II, it is suggested that the hydrogen bonds (Figures $1 \mathrm{c}$ and $2 \mathrm{~d}$ ) between two alkoxyethanol molecules assist alkoxyethanol molecules coordinating to $\mathrm{Cd}(\mathrm{II})$ ions. In other words, it is suggested that the alkoxyethanol dimer $\left(\mathrm{RCH}_{2} \mathrm{CH}_{2} \mathrm{OH}\right)_{2}$ serves as a template for $\mathrm{Cd}(\mathrm{CN})_{2}$ frameworks. Complex II contains two kinds of coordination geometries of the $\mathrm{Cd}(\mathrm{II})$ ions by total capacity of the $\mathrm{Cd}(\mathrm{CN})_{2}$ framework. The coordination geometries of $\mathrm{Cd}(\mathrm{II})$ ions and $\mathrm{Cd}(\mathrm{CN})_{2}$ framework structures depended on the difference of alkyl chains for alkoxyethanol molecules.

Supplementary Materials: The following are available online at http://www.mdpi.com/2073-4352/6/9/103/s1, Figure S1: TG and DTG plots of I, Figure S2: TG and DTG plots of II, Figure S3: TG and DTG plots of III, CdCN2_Rcel.cif: Crystal analysis data for complexes I-III.

Acknowledgments: The work was supported by MEXT (Ministry of Education, Culture, Sports, Science, and Technology, Japan)-Supported Program for the Strategic Research Foundation at Private Universities, 2012-2016. This work was also partly supported by JSPS KAKENHI Grant Number JP15K05485. We thank Yoshihiro Inoguchi of Toho University for preparation of complexes II and III.

Author Contributions: Takafumi Kitazawa conceived and designed the experiments; Takeshi Kawasaki performed the experiments and analyzed data; Takeshi Kawasaki and Takafumi Kitazawa wrote the paper.

Conflicts of Interest: The authors declare no conflict of interest.

\section{References}

1. Kitazawa, T.; Nishikiori, S.; Kuroda, K.; Iwamoto, T. Novel Clathrate Compound of Cadmium Cyanide Host with an Adamantane-like Caity. Cadmium Cyanide-Carbon Tetrachloride(1/1). Chem. Lett. 1988, 17, 1729-1732. [CrossRef]

2. Phillips, A.E.; Goodwin, A.L.; Halder, G.J.; Southon, P.D.; Kepert, C.J. Nanoporosity and Exceptional Negative Thermal Expansion in Single-Network Cadmium Cyanide. Angew. Chem. Int. Ed. 2008, 47, 1396-1399. [CrossRef] [PubMed]

3. Kitazawa, T. A new mineralomimetic $\mathrm{Cd}(\mathrm{CN})_{2}$ host framework which is intermediate between $\mathrm{H}-$ and L-cristobalite-like frameworks. Chem. Commun. 1999, 10, 891-892. [CrossRef]

4. Kitazawa, T. A new type of mineralomimetic cadmium cyanide host framework containing methyl acetate. J. Mater. Chem. 1998, 8, 671-674. [CrossRef]

5. Kitazawa, T.; Nishikiori, S.; Kuroda, K.; Iwamoto, T. Two novel metal-complex host structures consisting of cyanocadmate coordination polyhedra. Clay-like and zeolite-like structures. Chem. Lett. 1988, 17, 459-462. [CrossRef]

6. Nishikiori, S.; Ratcliffe, C.I.; Ripmeester, J.A. Crystal Structure of $\mathrm{Cd}_{5}(\mathrm{CN})_{10}\left(\mathrm{H}_{2} \mathrm{O}\right)_{4} \cdot 4 \mathrm{C}_{6} \mathrm{H}_{11} \mathrm{OH}$ Studied by X-ray Diffraction and Solid-State ${ }^{113} \mathrm{Cd}$ NMR. A New Type of Cristobalite-like Framework Host with a Site Interacting with Cyclohexanol by Hydrogen Bonding. J. Am. Chem. Soc. 1992, 114, 8590-8595. [CrossRef]

7. Kim, J.; Whang, D.; Lee, J.I.; Kim, K. Guest-dependent $\left[\mathrm{Cd}(\mathrm{CN})_{2}\right]_{n}$ Host Structures of Cadmium Cyanide-Alcohol Clathrates: Two New $\left[\mathrm{Cd}(\mathrm{CN})_{2}\right]_{n}$ Frameworks formed with $\operatorname{Pr}^{\mathrm{n}} \mathrm{OH}$ and $\operatorname{Pr}^{\mathrm{i} O H}$ Guests. J. Chem. Soc. Chem. Commun. 1993, 18, 1400-1402. [CrossRef]

8. Kim, J.; Whang, D.; Koh, Y.-S.; Kim, K. Two New $\left[\mathrm{Cd}(\mathrm{CN})_{2}\right]_{n}$ Frameworks with Linear Channels of Large, Elongated Hexagonal Cross-section: Structures of Cadmium Cyanide-Guest (Guest = dmf and $\mathrm{Me}_{2} \mathrm{SO}$ ) Clathrates. J. Chem. Soc. Chem. Commun. 1994, 5, 637-638. [CrossRef]

9. Kitazawa, T.; Kukuyama, T.; Takahashi, M.; Takeda, M. Cadmium Cyanide-Ether Clathrates: Crystal Structures of $\mathrm{Cd}_{8}(\mathrm{CN})_{16}\left(\mathrm{H}_{2} \mathrm{O}\right)_{6} \cdot 6 \mathrm{G}\left(\mathrm{G}=\mathrm{Et}_{2} \mathrm{O}\right.$ or $\left.\operatorname{Pr}_{2}{ }^{\mathrm{i}} \mathrm{O}\right)$ and $\mathrm{Cd}_{3}(\mathrm{CN})_{6}\left(\mathrm{H}_{2} \mathrm{O}\right)_{2} \cdot 2 \operatorname{Pr}_{2} \mathrm{O}$. J. Chem. Soc. Dalton Trans. 1994, 20, 2933-2937. [CrossRef]

10. Abrahams, B.F.; Hoskinis, B.F.; Lam, Y.-H.; Robson, R.; Separovic, F.; Woodberry, P. A Reexamination of the Structure of "Honeycomb Cadmium Cyanide". J. Solid State Chem. 2001, 156, 51-56. [CrossRef]

11. Nishikiori, S. Reversible reconstructive transition of the $\left[\mathrm{CuZn}(\mathrm{CN})_{4}\right]^{-}$framework host induced by guest exchange. CrystEngComm 2014, 16, 10173-10176. [CrossRef]

12. Nishikiori, S.; Ratcliffe, C.I.; Ripmeester, J.A. ${ }^{113}$ Cd NMR studies of Hofmann-type clathrates and related compounds: Evidence form two room temperature orientational glasses. Can. J. Chem. 1990, 68, 2270-2273. [CrossRef] 
13. Nishikiori, S.; Ratcliffe, C.I.; Ripmeester, J.A. Framework ordering in solid cadmium cyanides from cadmium-113 NMR spectroscopy. J. Chem. Soc. Chem. Commun. 1991, 10, 735-736. [CrossRef]

14. Flack, H.D. On enantiomorph-polarity estimation. Acta Crystallogr. Sect. A 1983, 39, 876-881. [CrossRef]

15. Addison, A.W.; Rao, T.N.; Reedijk, J.; van Rijin, J.; Verschoor, G.C. Synthesis, structure, and spectroscopic properties of copper(II) compounds containing nitrogen-sulphur donor ligands; the crystal and molecular structure of aqua[1,7-bis(N-methylbenzimidazol-2'-yl)-2,6-dithiaheptane]copper(II) perchlorate. J. Chem. Soc. Dalton Trans. 1984, 7, 1349-1356. [CrossRef]

16. Siewe, A.D.; Kim, J.-Y.; Kim, S.; Park, I.-H.; Lee, S.S. Regioisomer-Dependent Endo- and Exocyclic Coordination of Bis-Dithiamacrocycles. Inorg. Chem. 2014, 53, 393-398. [CrossRef] [PubMed]

17. Blatov, V.A.; Delgado-Friedrichs, O.; O'Keeffe, M.; Proserpio, D.M. Three-periodic nets and tilings: Natural tilings for nets. Acta Crystallogr. Sect. A 2007, 63, 418-425. [CrossRef] [PubMed]

18. Anurova, N.A.; Blatov, V.A.; Ilyushin, G.D.; Proserpio, D.M. Natural Tilings for Zeolite-Type Frameworks. J. Phys. Chem. C 2010, 114, 10160-10170. [CrossRef]

19. Bryant, M.R.; Burrows, A.D.; Fitchett, C.M.; Hawes, C.S.; Hunter, S.O.; Keenan, L.L.; Kelly, D.J.; Kruger, P.E.; Mahon, M.F.; Richardson, C. The synthesis and characterisation of coordination and hydrogen-bonded networks based on 4-(3,5-dimethyl-1H-pyrazol-4-yl)benzoic acid. Dalton Trans. 2015, 44, 9269-9280. [CrossRef] [PubMed]

20. Bruker. APEX2, version 2.0-2; Bruker AXS Inc.: Madison, WI, USA, 2006.

21. Bruker. SAINT, version 7.23A; Bruker AXS Inc.: Madison, WI, USA, 2007.

22. Bruker. SMART, version 5.625; Bruker AXS Inc.: Madison, WI, USA, 2003.

23. Bruker. SAINT, version 6.22; Bruker AXS Inc.: Madison, WI, USA, 2003.

24. Sheldrick, G.M. SADABS: Program for Empirical Absorption Correction; University of Göttingen: Göttingen, Germany, 1996.

25. Sheldrick, G.M. Crystal structure refinement with SHELXL. Acta Crystallogr. Sect. C 2015, 71, 3-8. [CrossRef] [PubMed]

26. Spek, A.L. Structure validation in chemical crystallography. Acta Crystallogr. Sect. D 2009, 65, 148-155. [CrossRef] [PubMed] 